\section{Landscape Preferences and Water Conservation Choices of Residents in a High Desert Environment}

\author{
Rolston St. Hilaire ${ }^{1,4}$, Dawn M. VanLeeuwen ${ }^{2}$, and Patrick Torres ${ }^{3}$
}

AdDITIONAL INDEX WORDs. arid, opinion survey, Santa Fe, semi-arid, urban

SumMary. We surveyed homeowners with residential landscapes in Santa Fe, NM, to determine their attitudes toward high desert plants and to assess their preferences for urban landscapes and water conservation strategies in a high desert urban environment. While there was low acceptance for the traditional turf lawn, $64 \%$ of residents agreed that high desert plants provided the variety they needed in their residential landscapes and $92 \%$ of residents would use high desert plants to landscape their front yard. Homeowners had a strong preference for retaining their current desert landscapes and converting traditional landscapes to high desert-adapted landscapes. Logistic regression revealed a negative relationship between length of residency in the southwestern United States and the willingness to use high desert plants. When homeowners who irrigated their landscape were asked whether water shortages, environmental concerns, information on water, city regulations, high water bills, or water rate increases would cause them to use less water on their landscapes, the highest level of agreement (94\%) was for water shortages. Eightyeight percent of respondents agreed that they liked any type of landscape that contains interesting features and is well planned. We conclude that homeowners have a preference for desert-adapted landscapes and agree that high desert plants provide an adequate palette of plants for urban landscapes. Additionally, the length of residency in the southwestern U.S. and the possibility of water shortages have the potential to impact water conservation strategies in high desert urban landscapes.

$\mathrm{U}$ rban areas in arid and semiarid regions continue to face water supply and demand challenges (St. Hilaire et al., 2008). Some of the drivers of these challenges include accelerated population growth and enhanced economic activity of urban areas. Thus, the urban landscape is one area that is a target for water conservation. This might be due to two reasons: 1) the urban landscape is highly visible to the public and is apt to be regulated, and 2) increasing urbanization is favoring a shift in consumptive water use from the traditional areas of high water use, such as agriculture, to residential use. $\mathrm{Mu}$ nicipalities can mandate communitywide water conservation measures, but

Contribution of the New Mexico Agricultural Experiment Station, New Mexico State University, Las Cruces.

We thank Daniel Ransom and the city of Santa Fe for assistance with the municipal utility database.

${ }^{1}$ Department of Plant and Environmental Sciences, New Mexico State University, Box 30003, Las Cruces, NM 88003

${ }^{2}$ Agricultural Biometric Service, New Mexico State University, Las Cruces, NM 88003

${ }^{3}$ Cooperative Extension Service, New Mexico State University, Santa Fe County Extension Office, Santa Fe, NM 87507

${ }^{4}$ Corresponding author. E-mail: rsthilai@nmsu.edu. individuals, and in particular, homeowners, also can make significant contributions to water conservation in the urban environment (Grisham and Fleming, 1989). Research that gains insight about the attitudes of homeowners can yield information about their preferred landscape or landscape water conservation strategy.

Knowledge of the preferred environments and water-conservation attitudes of residents often reveals differences among communities, which is useful for crafting long-term water conservation strategies. For example, in Arizona, although Tucson and Phoenix residents indicated preference for parks with irrigated turf, Phoenix residents indicated a stronger preference (Zube et al., 1986). A survey of residents in the New Mexican cities of Albuquerque, Las Cruces, and Santa Fe revealed broad support to decrease grass lawns and increase landscape space dedicated to native, natural, and water-conserving landscapes (Hurd et al., 2006). New Mexicans have further indicated that in the face of drought, the action they would be most likely to take to reduce landscape water use would be to replace turfgrass with drought-tolerant plants (J.R. Brown, N. Carrillo, and H. Jenkins-Smith, unpublished data).

Public opinion surveys are used to gain knowledge of residents' preferred landscape elements (St. Hilaire et al., 2003), landscapes (Yabiku et al., 2008), landscape preferences and practices (Martin et al., 2003), preferred plant colors (Kaufman and Lohr, 2008), water-conserving landscapes (Lockett et al., 2002), and attitudes toward water resource stewardship (Hurd et al., 2006). Attitudes toward water-conserving landscapes can be changed through educational efforts. Even a brief video that expresses more positive attitudes toward water-conserving landscapes can alter people's attitudes toward those landscapes (Lohr and Bummer, 1992).

A survey of New Mexico residents in Albuquerque, Las Cruces, and Santa Fe showed that water was one of the most important issues for the state (Hurd et al., 2006). While a 2004 study explored how plants and urban landscapes contribute to the landscape water conservation strategy of Las Cruces residents (Spinti et al., 2004), how Santa Fe homeowners balance their selection of urban landscapes with the need to conserve water is unknown.

Santa Fe, NM, is a high desert city $[7000 \mathrm{ft}(2133.6 \mathrm{~m})$ above sea level], and is the oldest capital city in the United States. Santa Fe has among the highest water rates in the United States for a city of its size and water price increases were related to a reduction in per capita water consumption between 1974 and 1985 (Grisham and Fleming, 1989). Santa Fe has a long history of water conservation. The objectives of this study were to use a public opinion survey of Santa Fe homeowners to identify the valued landscape features of urban landscapes, to determine current characteristics and the desired future changes of urban landscapes, and to determine the factors that affect the willingness of residents to reduce water use in the urban landscape.

\section{Materials and methods}

A survey was mailed to determine homeowner perceptions of desert plants, trees, and grass lawns in their landscapes, the status of their current landscape and their willingness to change their current landscape, their 
opinions on their current water use practices, and the factors that could affect their willingness to reduce water use. Participants also were asked about their reasons for landscaping and their landscape preferences. The survey instrument was based on one developed for the desert city of Las Cruces (St. Hilaire et al., 2003), but modified after the survey was pretested with 23 Santa Fe Master Gardeners. The survey instrument was modified to include suggested revisions of the Master Gardeners. For example, the term "desert plant" was replaced with "high desert plant." High desert plants thrive in the high altitude environments of semiarid regions and include plants such as rubber rabbitbrush (Ericameria nauseosa) and gambel's oak (Quercus gambelii).

The questionnaire contained five-point Likert-scaled items (Ary et al., 1996), multiple choice, dichotomous, and open-ended questions. The scaled value for each response category was as follows: strongly disagree $=1$, disagree $=2$, undecided $=3$, agree $=4$, and strongly agree $=5$. Respondents were asked to select one option from three possible answers to represent their answer to multiple choice questions. Dichotomous questions solicited a positive or negative response. A typical open-ended question was "How long have you been in your current home?"

We followed Dillman's protocol for mail survey (Dillman, 2000). Survey materials included a cover letter that described the purpose of the survey and the value of each response. We also included a raffle form for a chance to win one of five $\$ 50$ Wal-Mart gift certificates and a preaddressed stamped envelope for returning the completed survey and raffle tickets. Reminder postcards were mailed 1 week after the first mailing. On 21 Oct. 2004, 379 surveys were mailed to residential homeowners who were selected randomly from 23,716 names in the municipal utility database of Santa Fe. A population of 23,716 requires a random sample of 378 (Krejcie and Morgan, 1970). On 7 Nov. 2004, a second survey was mailed to nonrespondents. Replies from early and late responders, compared using chisquare and $t$ tests, were statistically similar. Consequently, the two data sets were combined. The cutoff date for survey return was set at 30 Mar. 2005.
After correcting for undeliverable addresses, the final response rate was $30 \%$.

DATa AnAlysis. Data were analyzed using SAS (version 9.1.3; SAS Institute, Cary, NC). Frequencies and percentage of distributions are presented for individual items. In addition, a hierarchical linear model was used to compare items within subscales using least squares means. To apply the model, positively phrased items were scored with strongly agree $(\mathrm{SA})=5$, agree $(\mathrm{A})=4$, undecided/neutral $(\mathrm{U})=3$, disagree $(\mathrm{D})=2$, and strongly disagree $(\mathrm{SD})=1$. Negatively phrased items were reverse scored with $\mathrm{SA}=5$, $\mathrm{A}=4, \mathrm{U}=3, \mathrm{D}=2$, and $\mathrm{SD}=1$. We included negative and positive survey items to keep respondents thinking about each item. The use of mixed negative and positive items reduces the possibility of respondents falling into patterned responses (Stewart et al., 2006). The correlation among responses from the same subject was accounted for using an unstructured covariance structure and the $\mathrm{ddfm}=$ KR option was used to adjust denominator df and standard errors.

High desert plant, grass lawn, and tree preference scores were obtained by computing subscale means based on the scoring indicated above. Reliabilities for these subscales were assessed using Cronbach's alpha, yielding 0.90 for desert plants, 0.81 for grass lawn, and 0.73 for trees. Paired $t$ tests were used to compare high desert plant, grass lawn, and tree preferences.

Associations between selected categorical variables were assessed using Fisher's exact test. Associations

Table 1. Responses of Santa Fe, NM, respondents $(n=93)$ to survey items asking feelings about trees in a yard. Participants were asked to give their level of response after being presented with the statement, "The most important reasons for landscaping are..." Survey items are arranged in decreasing order of positive attitude based on least squares means.

\begin{tabular}{|c|c|c|c|c|c|c|}
\hline \multirow[b]{3}{*}{ Survey item } & \multicolumn{6}{|c|}{ Response (\%) } \\
\hline & \multicolumn{6}{|c|}{ Response category ${ }^{z}$} \\
\hline & SA & A & $\mathrm{U}$ & $\mathrm{D}$ & SD & $\begin{array}{c}\text { Least squares } \\
\text { means }\end{array}$ \\
\hline Trees make an area more beautiful & 63.5 & 35.4 & 1.0 & 0.0 & 0.0 & $1.4 \mathrm{c}^{\mathrm{y}}$ \\
\hline I value the shade provided by trees & 54.1 & 42.7 & 2.1 & 0.0 & 1.0 & $1.5 \mathrm{bc}$ \\
\hline $\begin{array}{l}\text { Trees are part of the landscape I } \\
\text { desire }\end{array}$ & 55.3 & 40.4 & 2.1 & 2.1 & 0.0 & $1.5 \mathrm{~b}$ \\
\hline Trees increase the value of a home & 46.8 & 42.7 & 9.4 & 0.0 & 1.0 & $1.7 \mathrm{~b}$ \\
\hline Trees create too much litter $(\mathrm{R})^{\mathrm{x}}$ & 0.0 & 13.5 & 12.5 & 51.0 & 22.9 & $2.2 \mathrm{a}$ \\
\hline Tree produce too much pollen $(\mathrm{R})$ & 2.1 & 7.4 & 27.3 & 47.3 & 15.7 & $2.3 \mathrm{a}$ \\
\hline
\end{tabular}

${ }^{2}$ Strongly agree (SA), agree (A), undecided/neutral (U), disagree (D), or strongly disagree (SD).

y Least squares means with the same group letter do not differ significantly at $P \leq 0.05$.

${ }^{x}$ Items followed by an $(R)$ were reverse scored with $S A=5$ and $S D=1$. Other items were scored 1 (SA) to 5 (SD). 
Table 2. Responses of Santa Fe, NM, respondents $(n=93)$ to survey items asking feelings about grass lawns in a yard. Survey items are arranged in decreasing order of positive attitude based on least squares means.

\begin{tabular}{|c|c|c|c|c|c|c|}
\hline \multirow[b]{3}{*}{ Survey item } & \multicolumn{6}{|c|}{ Response (\%) } \\
\hline & \multicolumn{6}{|c|}{ Response category $^{z}$} \\
\hline & SA & A & $\mathrm{U}$ & D & SD & $\begin{array}{c}\text { Least squares } \\
\text { means }\end{array}$ \\
\hline Grass is familiar & 20.2 & 54.3 & 13.8 & 5.3 & 6.4 & $2.2 \mathrm{c}^{\mathrm{y}}$ \\
\hline A grass lawn is cooler & 25.3 & 43.2 & 17.9 & 9.5 & 4.2 & $2.2 \mathrm{c}$ \\
\hline $\begin{array}{l}\text { Grass provides a play } \\
\text { area for children }\end{array}$ & 20.0 & 53.7 & 10.5 & 9.5 & 6.3 & $2.3 \mathrm{c}$ \\
\hline $\begin{array}{l}\text { Grass provides a place } \\
\text { to play outside }\end{array}$ & 19.4 & 46.2 & 17.2 & 12.9 & 4.3 & $2.4 \mathrm{c}$ \\
\hline $\begin{array}{l}\text { Grass provides a contrast } \\
\text { to the desert }\end{array}$ & 9.7 & 57.0 & 22.6 & 5.4 & 5.4 & $2.4 \mathrm{c}$ \\
\hline $\begin{array}{l}\text { Grass often looks } \\
\text { unattractive }(\mathrm{R})^{\mathrm{x}}\end{array}$ & 6.6 & 37.3 & 18.7 & 24.2 & 13.2 & $3.0 \mathrm{~b}$ \\
\hline $\begin{array}{l}\text { Grass is desirable } \\
\text { for landscaping }\end{array}$ & 10.8 & 28.0 & 17.2 & 26.9 & 17.2 & $3.1 \mathrm{~b}$ \\
\hline $\begin{array}{l}\text { Grass requires a lot of } \\
\text { maintenance }(\mathrm{R})\end{array}$ & 52.2 & 36.7 & 4.4 & 5.6 & 1.1 & $4.3 \mathrm{a}$ \\
\hline
\end{tabular}

${ }^{2}$ Strongly agree (SA), agree (A), undecided/neutral (U), disagree (D), or strongly disagree (SD).

yeast squares means with the same group letter do not differ significantly at $P \leq 0.05$.

'Items followed by an $(\mathrm{R})$ were reverse scored with $\mathrm{SA}=5$ and $\mathrm{SD}=1$. Other items were scored $\mathrm{l}$ (SA) to 5 (SD).

Table 3. Responses of Santa Fe, NM, respondents $(n=93)$ to survey items asking feelings about using high desert plants in landscapes. Survey items are arranged in decreasing order of positive based on least squares means. Survey items had the form "High desert plants..."

\begin{tabular}{|c|c|c|c|c|c|c|}
\hline \multirow[b]{3}{*}{ Survey item } & \multicolumn{6}{|c|}{ Response (\%) } \\
\hline & \multicolumn{6}{|c|}{ Response category $^{z}$} \\
\hline & SA & A & $\mathrm{U}$ & D & SD & $\begin{array}{c}\text { Least squares } \\
\text { means }\end{array}$ \\
\hline ...cannot be found $(\mathrm{R})^{\mathrm{y}}$ & 0.0 & 5.3 & 12.7 & 37.2 & 44.6 & $1.8 \mathrm{f}^{\mathrm{x}}$ \\
\hline ....are not available & 0.00 & 7.6 & 15.2 & 41.3 & 35.9 & $1.9 \mathrm{e}$ \\
\hline ...look attractive & 28.4 & 53.7 & 9.5 & 6.3 & 2.1 & $2.0 \mathrm{e}$ \\
\hline $\begin{array}{l}\text {...provide the landscape } \\
\text { I desire }\end{array}$ & 28.1 & 50.0 & 11.5 & 8.3 & 2.1 & $2.1 \mathrm{de}$ \\
\hline $\begin{array}{l}\text {...do not provide } \\
\text { enough variety }(\mathrm{R})\end{array}$ & 1.0 & 14.7 & 21.0 & 28.4 & 34.7 & $2.2 \mathrm{~cd}$ \\
\hline $\begin{array}{l}\text {...provide the variety } \\
\text { I desire }\end{array}$ & 20.0 & 44.2 & 22.1 & 9.5 & 4.2 & $2.3 \mathrm{bc}$ \\
\hline ... are too expensive $(\mathrm{R})$ & 3.2 & 7.4 & 31.6 & 34.7 & 23.2 & $2.3 \mathrm{bc}$ \\
\hline ...provide enough green & 17.9 & 47.4 & 20.0 & 9.5 & 5.3 & $2.4 \mathrm{bc}$ \\
\hline $\begin{array}{l}\text {..look too much like } \\
\text { the high desert }(\mathrm{R})\end{array}$ & 5.4 & 16.1 & 20.4 & 43.0 & 15.0 & $2.5 \mathrm{~b}$ \\
\hline $\begin{array}{l}\text {...are not my favorite } \\
\text { plants }(\mathrm{R})\end{array}$ & 7.3 & 24.0 & 26.0 & 27.1 & 16.6 & $2.8 \mathrm{a}$ \\
\hline
\end{tabular}

${ }^{2}$ Strongly agree (SA), agree (A), undecided/neutral (U), disagree (D), or strongly disagree (SD).

${ }^{y}$ Items followed by an $(\mathrm{R})$ were reverse scored with $\mathrm{SA}=5$ and $\mathrm{SD}=1$. Other items were scored 1 (SA) to 5 (SD). ${ }^{x}$ Least squares means with the same group letter do not differ significantly at $P \leq 0.05$.

Martin et al. (2003) found that urban landscapes in Phoenix, AZ, communities with covenants, codes, and restrictions that mandated the landscape activity had fewer trees and less turf and more shrubs and groundcovers than landscapes in communities without those mandates. Therefore, it is hardly surprising that the traditional lawn represented fewer than $3 \%$ of the reported landscape types in Santa Fe (Hurd et al., 2006).

Most respondents agreed or strongly agreed that trees make areas more beautiful, provide valued shade, are a desirable part of the landscape, and increase the value of a home ( $\mathrm{Ta}$ ble 1). About $74 \%$ of the respondents disagreed or strongly disagreed with the statement that trees create too much litter (Table 1). Only 9\% of respondents agreed or strongly agreed that trees produce too much pollen. Responses to these items are similar to those reported in a survey of Las Cruces, NM, residents (Spinti et al., 2004), aside from one notable exception: a higher percentage of respondents agreed with trees' negative aspects. In the Las Cruces, NM, survey, about 33\% agreed that trees produce too much pollen, and about $32 \%$ agreed that they produce too much litter. One major reason for this difference is that Las Cruces may be perceived to have a high percentage of heavy pollen-producing trees such as mulberry (Morus spp.). Although the City of Las Cruces has not planted mulberries since the early 1990s, wellpublished, homeowner-driven petitions to ban mulberries from new landscapes in Las Cruces and the prevalence of those trees in existing landscapes (Parks and Recreation Advisory Board, 2004) may have raised homeowners' awareness of the pollen allergenic potential of those trees.

While the majority of respondents indicated that trees are a desirable landscape feature (Table 1), only about $39 \%$ of respondents agreed that the grass is desirable for landscaping (Table 2). Although a preponderance of respondents exhibited some level of agreement with statements that grass is familiar, cooler, provides a play area for children, as well as a place to lie outside, and is a contrast to the desert, $89 \%$ also agreed that grass requires a lot of maintenance. We included the 'grass is familiar' survey item to gauge the respondents' familiarity with the grass lawn in an urban setting. The item on the maintenance involved with grass was significantly more negatively rated than any other item and contributed to the overall higher mean of the grass subscale. Respondents were divided on whether grass often looks unattractive, with about $44 \%$ agreeing with the statement that grass often looks unattractive, and about $37 \%$ disagreeing.

About $78 \%$ of respondents agreed that high desert plants provide the landscape they desire (Table 3 ). This can be compared with the nearly $96 \%$ that agreed with this statement for trees (Table 1), and contrasted with the only $39 \%$ that indicated that 
grass is desirable for landscaping ( $\mathrm{Ta}-$ ble 2). People favor landscapes with trees (Schroeder and Cannon, 1987; Spinti et al., 2004), thus it is not surprising that there was strong agreement with the statement that trees provide the landscapes they desired. About $82 \%$ agreed that high desert plants look attractive (Table 3 ). For most respondents, availability and expense of desert plants were not negatives. About $77 \%$ disagreed with a statement that high desert plants are not available, and 58\% disagreed with a statement that they are too expensive (Table 3). However, the expense of high desert plants does present a concern for some people, as nearly $11 \%$ of respondents agreed with the statement that they are too expensive. But taken together, respondents data on variety and cost of desert plants indicate that high desert plants provide sufficient variety at a price point that satisfies most survey respondents.

About 64\% agreed that high desert plants provide the variety they desire and about $65 \%$ agreed that they provide enough green. Even so, about $31 \%$ of respondents acceded that high desert plants are not their favorite plants (Table 3). This correlates with an earlier study in which Spinti et al. (2004) found that 39\% of homeowners in Las Cruces, NM, indicated that desert plants were not their favorite plants. One possible explanation why desert plants did not appeal to some respondents may be that many desertadapted plants are grayish green, a color that reflects more heat than bright green (Richards et al., 1986). However, people respond most positively to tree canopies if the foliage approximates the bright green of a young, growing tree (Kaufman and Lohr, 2008). About $58 \%$ of respondents expressed some level of disagreement and nearly $22 \%$ expressed agreement with a statement that desert plants look too much like the high desert (Table 3 ). Respondents in Las Cruces articulated similar sentiments, with $44 \%$ disagreeing and $25 \%$ agreeing with this statement (St. Hilaire et al., 2003).

Current LANDSCAPING AND WILLINGNESS TO CHANGE CURRENT LANDSCAPING. When asked to describe the landscaping in their front yard, $64 \%$ of respondents indicated southwestern U.S. high desert landscaping, $12 \%$ indicated traditional landscaping with turfgrass and nonnative trees, and $24 \%$ indicated other (Table 4). When asked whether they would be willing to use high desert plants to landscape their front yards, $92 \%$ responded that they would. Of those reporting that they currently had desert landscaping in their front yard, only 39\% reported that they would like to change their landscaping. This was lower than the percentage of respondents with traditional landscaping or with other types of landscaping who did wish to modify their landscaping $(73 \%$ and $65 \%$, respectively). The differences among these response distributions were significant, $(P=0.0323)$, indicating that Santa Fe residents have a preference for retaining their desert landscaping and altering their already low percentage of traditional landscape to more desert-adapted landscape.

For the landscape type in their backyard, $46 \%$ of respondents indicated high desert landscaping, 21\% traditional, and 33\% other (Table 4 ). Eighty-three percent of respondents indicated a willingness to use high desert plants to landscape their backyard. The relatively lower percentage of residents willing to use high desert plants in their backyard is consistent with the findings of Spinti et al. (2004). The majority of participants in that study showed that they would use desert plant to landscape their front yard $(80.3 \%)$ and backyard (56.3\%) (Spinti et al., 2004).

Respondents also were asked to rate how much tree, shrub, and lawn area vegetation they currently had in their yard by using a scale of none, some, and many. They were also asked whether they would like to have less, the same, or more of those same vegetation types. For trees and shrubs, the most frequent response was some (70\% and $71 \%$, respectively) followed by many (28\% for trees and $20 \%$ for shrubs). Previous studies show that residents in desert environments have a clear preference for trees because of their ability to shade the yard and house (Zube and Kennedy, 1990). For lawn area, the most frequent response was none $(63 \%)$ followed by some $(32 \%)$. This result is consistent with the observation that the grass lawn is not a popular landscape element in Santa Fe (Hurd et al., 2006). For trees and shrubs, there was no evidence of an
Table 4. Responses of Santa Fe, NM, respondents $(n=99)$ who reported the actual landscape type in their front yard and back yard.

\begin{tabular}{lcc}
\hline Item & $\begin{array}{c}\text { Front } \\
\text { yard (\%) }\end{array}$ & $\begin{array}{c}\text { Back } \\
\text { yard (\%) }\end{array}$ \\
\hline $\begin{array}{l}\text { Southwest } \\
\text { high desert }\end{array}$ & 64 & 46 \\
$\begin{array}{l}\text { Traditional } \\
\text { landscaping (turf, } \\
\text { nonnative trees) }\end{array}$ & 12 & 21 \\
$\begin{array}{l}\text { Other } \\
{ }^{2} \text { Column values do not add to } 100 \% \text { due to rounding. }\end{array}$
\end{tabular}

association between the amount they had and the amount they would like to have [Fisher's exact test: $P=$ 0.4050 (trees), $P=0.2049$ (shrubs)]. Most people reported that they would like to have the same amount (55.7\% trees and $59.8 \%$ shrubs). The next most common response expressed was a desire for more $(41.24 \%$ for trees and $38.14 \%$ for shrubs). For the grass lawn, however, there was a significant association between the amount currently in their yard and the desired amount (Fisher's exact test: $P$ $=0.0476)$. Of those reporting no lawn area, $57 \%$ indicated they wanted to keep that same amount, while $29 \%$ indicated they wanted more. The $14 \%$ who indicated less lawn area (although they had no lawn area), provides an opportunity for an interesting research question that warrants further inquiry. Of those reporting some lawn area, $43 \%$ indicated they wanted less, $17 \%$ indicated they wanted more, and $40 \%$ indicated they wanted the same amount. Only five people had reported a high amount of lawn area, consistent with the fact that waterintensive lawn area is not widespread in residential sites in Santa Fe.

A logistic regression with willingness to use desert plants to landscape the backyard as the response variable, and time in the southwestern United States as the explanatory variable was fit. The fitted equation was logit $=3.0047-0.0344 \times$ years, and reflecting a negative relationship between time in the desert southwestern U.S. and a willingness to use high desert plants. This result supports the findings of Spinti et al. (2004) and Martin et al. (2003) who also found a negative relationship between willingness to use desert plants and time in the southwestern United States. Similarly, renters living in a university 
housing complex on the Arizona State University campus in Mesa report that longer socialization to the desert environment decreased their preferences for arid landscapes.

Our findings are dissimilar to those of Kennedy and Zube (1991) and Lyons (1983) who reported that greater acceptance of desert landscaping is associated with greater familiarity with the desert environment. Those findings contrast with the item "My attitudes about high desert plants have become more positive over time" (Table 5) where nearly $85 \%$ of respondents agreed that their attitudes about high desert plants have become more positive over time. Because the current study is crosssectional, observed associations may be caused by secular trends and demographics. Consequently, older respondents who grew up with most landscaped areas falling into the traditional category may still have a bias toward traditional landscaping, even if they spent much of their life in the southwestern United States. In this survey, we defined traditional landscapes as those containing turfgrass and non-native trees. Respondents who have had shorter residency in the southwestern United States desert may have moved from other areas and become more accustomed to desert plants over time. Furthermore, high desert landscapes have been promoted heavily in recent years due to the ongoing drought in New Mexico, thus, the younger generation might be more influenced by, or more sensitive to, this environmental issue than older generations. Another possible explanation is that younger Santa Fe residents may be more adaptable, and thus more accepting of alternative landscaping. Alternately, the older generation might be sensi- tive to environmental issues but less able to make changes to their landscapes. Perhaps a longitudinal study of the impact of demographic trends on landscape preferences would parse out this issue.

WATER USE AND FACTORS AFFECTING WILLINGNESS TO REDUCE WATER USE. Ninety-three percent of respondents indicated that they water their landscape; the remainder, $7 \%$, indicated they do not. Although the demand for desert-adapted landscapes enjoys a stronger level of support in Santa Fe than in the desert cities of Albuquerque and Las Cruces, it is clear that most Santa Fe residents apply water to their landscapes. What warrants further study is whether residents, mindful of water conservation issues, are watering their desert-adapted landscapes less frequently or are applying less water because of diminished turf areas.

When homeowners who watered their landscapes were asked what factor would cause them to use less water on their landscape, the highest level of agreement was for water shortages. Environmental concerns received the next highest level of agreement $(\mathrm{Ta}-$ ble 6 ). Even so, nearly $70 \%$ or more agreed with the remaining factors: environmental concerns, city regulations, high water bills, and water rate increases. Overall, the pattern of response to these factors was very similar to that observed by Spinti et al. (2004), although respondents to the current survey indicated stronger agreement to the items on water shortages and environmental concerns. Martin and Kulakowski (1991) and McPherson and Haip (1989) reported that water rate increases were more effective in reducing water use than water shortages. While water rates are critical to long-term water conservation measures (Grisham and Fleming, 1989) and should be used as an urban water-use management tool, our results consistently show that water shortage is the factor most likely to engender a reduction of water use in the landscape. Municipalities should consider weaving the possibility of water shortages into water conservation public awareness campaigns to ensure maximum effectiveness.

LANDSCAPE PREFERENCES. When asked about landscape preferences, over $88 \%$ of respondents agreed that they liked any type of landscape with beautiful healthy plants and that they liked any type of landscape that looks well planned and contains interesting features (Table 5). While the least squares estimate for the item stating "I like any type of landscape that looks neat and well cared for" was higher (representing less agreement) than the least squares estimate for the first two items, $77 \%$ of respondents indicated some level of agreement with this statement. About $35 \%$ of respondents agreed with the statement "I like yards that provide a contrast to the surrounding desert," while $31 \%$ showed some level of disagreement with this statement. This statement had the least level of agreement among the statements that inquired about general landscape attitudes. These results suggest that plants that blend with the high desert ecosystem and are water-efficient would gain widespread acceptance in managed urban landscapes of Santa Fe. In fact, Nassauer (1988) reported that using plants that fit the ecology of a landscape environment is one way to demonstrate care for the landscape.

In an earlier study, Spinti et al. (2004) showed that residents of Las Cruces, NM, ranked making the yard and house more attractive as one of

Table 5. Responses of Santa Fe, NM, respondents $(n=99)$ to survey items asking general landscaping attitudes. Survey items are arranged in decreasing order of agreement based on least squares means.

\begin{tabular}{|c|c|c|c|c|c|c|}
\hline \multirow[b]{3}{*}{ Survey item } & \multicolumn{6}{|c|}{ Response (\%) } \\
\hline & \multicolumn{6}{|c|}{ Response category $^{\mathrm{z}}$} \\
\hline & SA & A & $\mathrm{U}$ & $\mathbf{D}$ & SD & $\begin{array}{c}\text { Least squares } \\
\text { means }\end{array}$ \\
\hline I like any type of landscape that has beautiful healthy plants & 43.3 & 45.4 & 5.2 & 6.2 & 0.0 & $1.7 \mathrm{c}^{\mathrm{y}}$ \\
\hline I like any type of landscape that looks well planned, with interesting features & 27.8 & 62.9 & 6.2 & 3.1 & 0.0 & $1.8 \mathrm{c}$ \\
\hline My attitudes about high desert plants have become more positive over time & 34.0 & 50.5 & 9.3 & 13.5 & 0.0 & $2.1 \mathrm{~b}$ \\
\hline I like any type of landscape that looks neat and well cared for & 31.2 & 45.8 & 9.4 & 13.5 & 0.0 & $2.1 \mathrm{~b}$ \\
\hline I like yards that provide a contrast from the surrounding desert & 9.4 & 26.0 & 33.3 & 17.7 & 13.5 & $3.0 \mathrm{a}$ \\
\hline
\end{tabular}

${ }^{2}$ Strongly agree (SA), agree (A), undecided/neutral (U), disagree (D), or strongly disagree (SD).

${ }^{y}$ Least squares means with the same group letter do not differ significantly at $P \leq 0.05$. 
Table 6. Responses of Santa Fe, NM, respondents $(n=99)$ who use water to survey items asking what would cause them to use less water on their landscape. Survey items are arranged in decreasing order of agreement based on least squares means.

\begin{tabular}{|c|c|c|c|c|c|c|}
\hline \multirow[b]{3}{*}{ Survey item } & \multicolumn{6}{|c|}{ Response (\%) } \\
\hline & \multicolumn{6}{|c|}{ Response category $^{z}$} \\
\hline & SA & A & $\mathrm{U}$ & D & SD & $\begin{array}{c}\text { Least squares } \\
\text { means }\end{array}$ \\
\hline Water shortages & 51.5 & 42.5 & 3.7 & 2.5 & 0.0 & $1.6 c^{y}$ \\
\hline Environmental concerns & 41.0 & 37.3 & 12.0 & 7.2 & 2.4 & $1.9 \mathrm{~b}$ \\
\hline Information on water & 25.6 & 47.6 & 14.6 & 9.8 & 2.4 & $2.2 \mathrm{a}$ \\
\hline City regulations & 21.6 & 53.0 & 13.2 & 8.4 & 3.6 & $2.2 \mathrm{a}$ \\
\hline High water bills & 27.7 & 43.4 & 13.2 & 12.0 & 3.6 & $2.2 \mathrm{a}$ \\
\hline Water rate increases & 27.7 & 42.2 & 14.5 & 12.0 & 3.6 & $2.2 \mathrm{a}$ \\
\hline
\end{tabular}

${ }^{2}$ Strongly agree (SA), agree (A), undecided/neutral (U), disagree (D), or strongly disagree (SD).

'Least squares means with the same group letter do not differ significantly at $P \leq 0.05$.

Table 7. Responses of Santa Fe, NM, respondents $(n=99)$ to survey items asking most important reasons to landscape their yard. Survey items are arranged in decreasing order of agreement based on least squares means.

\begin{tabular}{|c|c|c|c|c|c|c|}
\hline \multirow[b]{3}{*}{ Survey item } & \multicolumn{6}{|c|}{ Response (\%) } \\
\hline & \multicolumn{6}{|c|}{ Response category $^{z}$} \\
\hline & SA & A & $\mathrm{U}$ & D & SD & $\begin{array}{c}\text { Least squares } \\
\text { means } \\
\end{array}$ \\
\hline To make my yard more attractive & 63.3 & 34.7 & 1.0 & 0.0 & 1.0 & $1.4 \mathrm{e}^{\mathrm{y}}$ \\
\hline To make my house more attractive & 51.0 & 46.9 & 2.0 & 0.0 & 0.0 & $1.5 \mathrm{~d}$ \\
\hline To provide a place to relax & 40.8 & 45.9 & 5.1 & 8.2 & 0.0 & $1.8 \mathrm{c}$ \\
\hline To increase property value over time & 35.1 & 48.4 & 10.3 & 4.1 & 2.1 & $1.9 \mathrm{c}$ \\
\hline To provide shade & 27.5 & 54.1 & 12.2 & 6.1 & 0.0 & $2.0 \mathrm{c}$ \\
\hline $\begin{array}{l}\text { To screen the street or neighbors } \\
\text { houses/yards }\end{array}$ & 19.8 & 47.9 & 14.6 & 12.5 & 5.2 & $2.4 \mathrm{~b}$ \\
\hline To express my landscape preferences & 22.9 & 36.5 & 24.0 & 13.5 & 3.1 & $2.4 \mathrm{~b}$ \\
\hline To provide a place to play & 13.7 & 36.8 & 30.5 & 16.8 & 2.1 & $2.6 \mathrm{~b}$ \\
\hline $\begin{array}{l}\text { To create an area that contrasts with } \\
\text { a high desert }\end{array}$ & 8.3 & 24.0 & 20.8 & 32.3 & 14.6 & $3.2 \mathrm{a}$ \\
\hline
\end{tabular}

${ }^{\mathrm{z}}$ Strongly agree (SA), agree (A), undecided/neutral (U), disagree (D), or strongly disagree (SD).

'Least squares means with the same letter group do not differ significantly at $P \leq 0.05$.

the top reasons for landscaping. Residents of Santa Fe had the same top reasons when asked about the most important reasons to landscape their yard (Table 7). These reasons are followed in priority by providing a place to relax, increasing property value, and providing shade. A third set of items includes screening the street or neighbors' yards, expressing one's landscape preferences, and providing a place to play. Based on the least squares mean results, Santa Fe residents had the least agreement with the statement that creating an area of contrast to the desert was the most important reason to landscape their yard (Table 7 ). About 32\% of respondents reported agreement and nearly $47 \%$ reported some level of disagreement to this item. While Spinti et al. (2004) reported a higher percentage of neutral responses to this item, based on least squares mean scores, it was the least agreed upon item in their study as well.

The data in Tables 5 and 7 show that landscaping the yard to create a contrast with the desert was the least agreed upon statement. Furthermore, the item in Table 3 stating that high desert plants look too much like the high desert had 22\% agreement, but $58 \%$ disagreement. A similar item in Spinti et al. (2004) also had greater disagreement $(44 \%)$ than agreement $(34 \%)$. Taken together, these data suggest that having managed landscapes contrast with the desert is a low priority for most respondents in our study.

\section{Conclusions}

Municipalities can select the most effective strategies to reduce water use in the urban landscape if they understand how residents' landscape preferences affect water use. For the high desert city of Santa Fe, NM, a sound history of water conservation efforts and sensible ordinances have generated community support for landscapes that limit the use of turfdominated landscapes. Although almost one-third of the respondents agreed that high desert plants are not their favorite, most Santa Fe residents are satisfied with high desert plants, indicating that they provide the type of landscape they desire. A desirable landscape should include trees and be well-designed. On the other hand, a landscape that differs from the surrounding high desert environment is of very low preference for Santa Fe residents. We found more evidence that the longer people have resided in a desert environment, the less likely they are to adopt a water-conserving landscape. This offers many opportunities for water conservation in desert cities that sustain population growth through the addition of residents that are not indigenous to the desert environment. This research clearly indicates that the fear of water shortage is one of the most important factors that will get communities to reduce landscape water use in the high desert regions of New Mexico. Therefore, municipalities must craft public education water conservation programs that show or even simulate water shortages as a possible consequence of apathy to water conservation in the urban environment.

\section{Literature cited}

Ary, D., L.C. Jacobs, and A. Razavieh. 1996. Introduction to research in education. 5th ed. Harcourt Brace College Publishers, Orlando, FL.

Dillman, D.A. 2000. Mail and internet surveys: The tailored design method. 2nd ed. Wiley, New York.

Grisham, A. and W.M. Fleming. 1989. Long-term options for municipal water conservation. J. Amer. Water Works Assn. 81:34-42.

Hurd, B., R. St. Hilaire, and J. White. 2006. Residential landscapes, homeowner attitudes and water-wise choices in New Mexico. HortTechnology 16:241-246.

Kaufman, A.J. and V.I. Lohr. 2008. Does it matter what color tree you plant? Acta Hort. 790:179-184. 
Kennedy, C.B. and E.H. Zube. 1991. Attitudes towards vegetation in a desert urban forest: Creating a sense of place. J. Arboriculture 17:159-166.

Krejcie, R.V. and D.W. Morgan. 1970. Determining sample size for research activities. Educ. Psychol. Meas. 30:607-610.

Lockett, L., T. Montague, C. McKenney, and D. Auld. 2002. Assessing public opinion on water conservation and water conserving landscapes in the semiarid southwestern United States. HortTechnology 12:392-396.

Lohr, V.I. and L.H. Bummer. 1992. Assessing and influencing attitudes toward water-conserving landscapes. HortTechnology 2:253-256.

Lyons, E. 1983. Demographic correlates of landscape preference. Environ. Behav. $15: 487-511$.

Martin, C.A., K.A. Peterson, and L.B. Stabler. 2003. Residential landscaping in Phoenix, Arizona, U.S.: Practices and preferences relative to covenants, codes, and restrictions. J. Arboriculture 29:9-16.

Martin, W.E. and S. Kulakowski. 1991. Water price as a policy variable in managing urban water use: Tucson, Arizona. Water Resour. Res. 27:157-166.

McPherson, E.G. and R.A. Haip. 1989. Emerging desert landscape in Tucson. Geogr. Rev. 79:435-449.
Nassauer, J.I. 1988. The aesthetics of horticulture: Neatness as a form of care. HortScience 23:973-977.

Parks and Recreation Advisory Board. 2004. Minutes of the Park and Recreation Advisory Board of Las Cruces, 27 July 2004. 3 Feb. 2008. <http://www.las-cruces. org/Boards $\% 20$ Commissions $\% 20$ and $\%$ 20Committees/Parks\%20and\%20Recreation\% $20 \mathrm{Advis}$ ory $\% 20 \mathrm{Board} / \mathrm{Minutes} /$ 072704\%20July\%2027,\%202004.doc>.

Richards, R.A., H.M. Rawson, and D.A. Johnson. 1986. Glaucousness in wheat: Its development and effect on water-use efficiency, gas exchange and photosynthetic tissue temperatures. Aust. J. Plant Physiol. 13:465-473.

St. Hilaire, R., J.E. Spinti, D. VanLeeuwen, and C. Smith. 2003. Landscape preferences and attitudes toward water conservation: A public opinion survey of homeowners in Las Cruces, New Mexico. New Mexico Agr. Expt. Sta. Res. Rpt. 750 .

St. Hilaire, R., M.A. Arnold, D.A. Devitt, B.H. Hurd, B.J. Lesikar, V.I. Lohr, C.A. Martin, G.V. McDonald, R.L. Morris, D.R. Pittenger, D.A. Shaw, D.C. Wilkerson, and D.F. Zoldoske. 2008. Efficient water use in residential urban landscapes. HortScience 43:2081-2092.

Santa Fe County Water Conservation Information. 2002. Santa Fe County Ordinance no. 2002-13. 30 June 2009. <http:// www.co.santafe.nm.us/about_us/water_ conservation_ordinances.php>.

Schroeder, H.W. and W.N. Cannon Jr. 1987. Visual quality of residential streets: Both street and yard trees make a difference. J. Arboriculture 13:236-239.

Spinti, J.E., R. St. Hilaire, and D. VanLeeuwen. 2004. Balancing landscape preferences and water conservation in a desert environment. HortTechnology 14:72-77.

Stewart, T.J., E. Roberts, P. Eleazer, R. Boland, and D. Wieland. 2006. Reliability and validity issues for two common measures of medical students' attitudes toward older adults. Educ. Gerontol. 32:409421.

Yabiku, S.T., D.G. Casagrande, and E. Farley-Metzger. 2008. Preferences for landscape choice in a Southwestern desert city. Environ. Behav. 40:382-400.

Zube, E.H. and C.B. Kennedy. 1990. Urban forests in the desert? J. Arboriculture 16:95-98.

Zube, E.H., D.E. Simcox, and C.S. Law. 1986. The oasis image of two desert cities. Landscape Res. 11:7-11. 